\title{
Acquired Congenital Heart Block
}

\section{Pattern of Maternal Antibody Response to Biochemically Defined Antigens of the SSA/Ro-SSB/La System in Neonatal Lupus}

\author{
Jill P. Buyon," Eldad Ben-Chetrit, ${ }^{\ddagger}$ Sharon Karp," Robert A. S. Roubey," Lisa Pompeo, \\ Westley H. Reeves, ${ }^{5}$ Eng M. Tan, ${ }^{\ddagger}$ and Robert Winchester* \\ *The Division of Rheumatology, Department of Medicine, and the Hospital for Joint Diseases, of the New York University Medical \\ Center, New York 10016; ${ }^{\ddagger} W$. M. Keck Autoimmune Disease Center, Scripps Clinic and Research Foundation, \\ La Jolla, California 92037; and ${ }^{\S}$ Rockefeller University, New York 10021
}

\section{Abstract}

The molecular basis of autoantibody reactivity with components of the SSA/Ro-SSB/La particle exhibited by sera of mothers of infants with severe and permanent manifestations of neonatal lupus (NLE) was investigated using immunoblotting and immunoprecipitation. The characteristics of NLE that were studied included congenital complete heart block (CCHB), second degree heart block, and hepatic fibrosis. Antibodies specific for one or more components of the SSA/RoSSB/La particle were found in sera from all 20 mothers of permanently affected infants. However, no antibody specific for a single peptide of this particle was common to all sera. Using tissue extracts from a human cell substrate, $80 \%$ of these sera had antibodies to one or more components of the SSA/Ro particle demonstrable by immunoblotting. The predominant antibody response in the NLE group was to the newly recognized $52-\mathrm{kD}$ SSA/Ro peptide component. In contrast, antibodies to the $60-\mathrm{kD}$ SSA/Ro component although present, were the least represented and not significantly increased in frequency among mothers of these infants, compared with a group of 31 mothers with autoimmune diseases such as systemic lupus erythromatosus (SLE) but who had healthy offspring. Antibodies directed to the 48-kD SSB/La antigen were demonstrated in $90 \%$ of the NLE mothers often accompanying antibodies against the 52-kD SSA/Ro component. The combination of antibodies to 48- and 52-kD structures was significantly increased in the NLE group, with an odds ratio of 35 . The type of cell or tissue substrate was shown to influence detectability of antibodies. The 52-kD SSA/Ro peptide and the 48-kD SSB/La peptide were abundant in cardiac tissues from fetuses aged 18-24 wk, further supporting the possible relevance of these peptides to heart block.

\section{Introduction}

The potentially severe and permanent manifestation of neonatal lupus (NLE), ${ }^{1}$ congenital complete heart block (CCHB)

Address reprint requests to Dr. Jill P. Buyon, Hospital for Joint Diseases, 301 East 17th Street, New York, New York 10003.

Received for publication 20 October 1988 and in revised form 13 February 1989.

1. Abbreviations used in this paper: ARA, American Rheumatism Association; CCHB, complete congenital heart block; NLE, neonatal lupus; SS, Sjögren's Syndrome.

J. Clin. Invest.

(C) The American Society for Clinical Investigation, Inc. 0021-9738/89/08/0627/08 \$2.00

Volume 84, August 1989, 627-634 appearing after the first trimester of pregnancy is significant both as a model for a passively acquired autoimmune disease and in terms of diagnosis and management. The mechanism of disease is considered to depend on the placental transport of maternal antibodies capable of initiating specific myocardial inflammation that permanently damages the conduction system of the developing fetal heart (1); however, the nature of the antigen-antibody system or systems involved in the injury of the fetal heart remains as a challenge for investigation.

The recognition that antibodies to the SSA/Ro ribonucleoprotein complex were found in as many as $85 \%$ of sera from mothers of infants with $\mathrm{CCHB}$ or other manifestations of passively acquired NLE such as skin or liver disease was an important advance, directing attention to this antigen as a potential candidate despite its intracellular location (2-6). The possibility that the SSB/La antigen-antibody system might also be involved in the development of CCHB has been suggested (7) because of the vast predominance of antibodies reactive with the SSB/La protein found in certain patients $(7,8)$, but no systematic study of the occurrence of antibodies to all elements of the SSA/Ro-SSB/La particle has been performed in the NLE group.

Knowledge of the structures that bear the SSA/Ro antigens, while still incomplete, is rapidly growing. The first major antigenic component of SSA/Ro to be described was a polypeptide of $60 \mathrm{kD}(9)$. This gene has been cloned (10). A protein sequence of a $60-\mathrm{kD}$ component has also been reported that differs in sequence from the $60-\mathrm{kD}$ species (11). Its occurrence and relationship to the $60-\mathrm{kD}$ species is currently unknown.

Using immunoblot techniques, another polypeptide in the human SSA/Ro complex has been identified as a 52-kD species (12). It has not yet been cloned or chemically purified nor has its presence in other species been studied. The $52-\mathrm{kD}$ protein is antigenically and structurally distinct from the $60-\mathrm{kD}$ protein (12). Both the $60-\mathrm{kD}$ and the $52-\mathrm{kD}$ SSA/Ro peptides are associated with four RNA species designated hY1, hY3, hY4, hY5 $(9,12)$. Other evidence for multiple forms of the SSA/Ro structure have been reported and that found in fetal red blood cells apparently associates with only two RNA species (13). Additionally there are species differences in the structure of the SSA/Ro complex, with only two RNA species, $\mathrm{mY} 1$ and $\mathrm{mY2}$, identified in the mouse (14). The presence of the SSA/Ro antigen in fetal cardiac tissue has been reported using immunofluorescence techniques (5), and a 60-kD SSA/ Ro polypeptide was biochemically identified (6).

The intricacy of the SSA/Ro polypeptide-RNA complex is further complicated by its association with the $48-\mathrm{kD} \mathrm{SSB} / \mathrm{La}$ protein forming a larger assembly $(9,15)$. The SSB/La protein does not share antigenic determinants with the SSA/Ro peptides and the genes encoding them show no homology $(16,17)$. The SSB/La component is complexed to a spectrum of RNAs 
that includes precursor forms of 5S rRNA and tRNA, certain small viral RNAs and the SSA/Ro-associated RNAs (18). In terms of biologic function, the SSB/La protein appears to be involved in the maturation of RNA polymerase III transcripts (18), probably in the termination of transcription (19).

This study was initiated to obtain a more precise molecular characterization of the relevant antigenic structures identified by the immune response in women with offspring with NLE, predominantly $\mathrm{CCHB}$, and to determine whether these components, particularly the 52-kD SSA/Ro peptide, are expressed in fetal cardiac tissue. The specific objectives included using the resolution of gel separation methods to define the apparent molecular masses of these autoantigens to determine whether one or both of the components of the SSA/Ro particle are recognized by antibodies in the sera of NLE mothers and whether antibodies to SSB/La are prevalent.

\section{Methods}

Patients' sera. Two groups of sera were evaluated. The first group consisted of sera obtained from 20 women having offspring with severe and permanent manifestations of NLE. 18 women (patients A-T, except $\mathrm{C}$ and I; see Table I) were either pregnant with a fetus documented by echocardiogram to have CCHB or had recently given birth to a child with CCHB. One woman (patient I) gave birth to an infant with second degree heart block and another (patient $\mathrm{C}$ ) had a child with neonatal skin disease and hepatic fibrosis in whom heart block was not documented. Of this group, two fulfilled a set of criteria for the diagnosis of Sjögren's Syndrome (SS) (20), five fulfilled American Rheumatism Association (ARA) criteria for the diagnosis of systemic lupus erythematosus (SLE) (21), and 13 were diagnosed as having an undifferentiated autoimmune state characterized by diverse autoantibodies and a clinical history insufficient to meet criteria of SLE, rheumatoid arthritis, or SS. The second group was composed of available sera obtained from all women who attended the lupus and Sjögren's clinic at the Hospital for Joint Diseases and Bellevue Hospital and had given birth to healthy offspring. This group contained serum from 31 patients (22 of whom were pregnant at the time of serum collection), representing $\sim 22 \%$ of the clinic population. Two of these patients were diagnosed as having SS, the remaining 29 as having SLE. It is recognized that a strictly comparable control group is difficult to assemble, as some of the mothers of offspring with NLE were asymptomatic or had only seemingly innocent complaints and the presence of autoantibodies was identified retrospectively (22).

Gel double diffusion (Ouchterlony). Antibodies to the SSA/Ro and SSB/La antigens were detected by using double immunodiffusion in 0.6\% agarose. Rabbit thymus extract (Pel-Freeze Biologicals, Rogers, AR), protein concentration $100 \mathrm{mg} / \mathrm{ml}$, was used as the source of SSB/La antigen, bovine spleen (Pel-Freeze), $100 \mathrm{mg} / \mathrm{ml}$, and extracts of human B cell lymphoblastoid line WIL-2 cells, protein concentration $20 \mathrm{mg} / \mathrm{ml}$ were used as sources of the SSA/Ro antigen. Reference sera were obtained from the Center for Disease Control, Atlanta, GA. Precipitin lines were formed after interaction of extract with 1:1 and 1:30 dilutions of sera and read after 24 and $48 \mathrm{~h}$ (12).

$E L I S A$. These assays were performed using commercially purified preparations of SSA/Ro from bovine spleen and SSB/La from rabbit thymus (Immunovision, Springdale, AR). SSA/Ro at $5 \mu \mathrm{g} / \mathrm{ml}$ or SSB/ $\mathrm{La}$ at $10 \mu \mathrm{g} / \mathrm{ml}$ in $0.05 \mathrm{M} \mathrm{NaHCO} / \mathrm{Na}_{2} \mathrm{CO}_{3}, \mathrm{pH} 9.2$, were incubated in 50-well enzyme immunoassay plates (Gilford Instrument Laboratories, Oberlin, $\mathrm{OH}$ ) overnight at $4^{\circ} \mathrm{C}$. Plates were washed and then blocked with $1 \%$ bovine serum albumin in PBS containing $0.05 \%$ Tween 20. Sera diluted 1:1000 in PBS containing 0.05\% Tween 20 were incubated for $90 \mathrm{~min}$ at room temperature. After washing, plates were incubated with $\mathrm{F}\left(\mathrm{ab}^{\prime}\right)_{2}$ goat anti-human IgG alkaline phosphatase conjugate (Sigma Chemical Co.) for $1 \mathrm{~h}$ at room temperature. Plates were then washed and developed with p-nitrophenyl phosphate, disodium (Sigma Chemical Co.) in diethanolamine buffer. Results were expressed as the optical absorbance at $405 \mathrm{~nm}$ less reagent blank. The mean value of 24 controls was $0.01(\mathrm{SD}=\mathbf{0 . 0 2}$ ) for SSA/Ro and 0.01 $(\mathrm{SD}=0.01)$ for SSB/La. Serial dilutions of positive sera revealed the relationship of antibody titer and optical density to be linear in the OD range 0.20 to 1.00 .

$P A G E$. SDS-PAGE was performed following the method described by Laemmli (23), in $15 \%$ acrylamide gel slabs. The following protein standards were used to determine molecular weights: phosphorylase B, $92.5 \mathrm{kD}$; BSA, $66.2 \mathrm{kD}$; ovalbumin, $45 \mathrm{kD}$; glyceraldehyde-3-phosphate dehydrogenase, $36 \mathrm{kD}$; carbonic anhydrase, $31 \mathrm{kD}$; soybean trypsin inhibitor, $21.5 \mathrm{kD}$; and lysozyme, $14.4 \mathrm{kD}$.

Preparation of cell tissue extracts and radiolabeling. Fresh fetal cardiac and liver tissue aged 18-24 wk were obtained after elective termination of normal pregnancy by dilation and evacuation. This was done in accordance with the guidelines of the Institutional Review Board and after obtaining the consent of the mothers. The tissues were minced and diluted in buffer containing $150 \mathrm{mM} \mathrm{NaCl}, 50 \mathrm{mM}$ Tris $\mathrm{HCl} \mathrm{pH} 7.4,3 \mathrm{mM} \mathrm{Na}$ EDTA, $0.02 \% \mathrm{NaN}_{3}, 0.5 \% \mathrm{NP}-40,1 \mathrm{mM}$ PMSF and centrifuged at $12,000 \mathrm{~g}$ for $15 \mathrm{~min}$. Supernatants were stored at $-70^{\circ} \mathrm{C}$ for use in immunoblot analysis.

The cell lines HeLa and WI-38 (American Type Culture Collection, Rockville, MD) were grown in monolayer cultures with DME containing $10 \%$ calf serum and $2.5 \mu \mathrm{g} / \mathrm{ml}$ gentamycin sulfate at $37^{\circ} \mathrm{C}$ in a $5 \% \mathrm{CO}_{2}$ incubator. Cultures were used at subconfluent densities. Cells were harvested by mechanical detachment. The standard cell lines MOLT4, derived from a patient with acute T cell lymphoblastic leukemia, and U937 from a patient with a histiocytic lymphoma, were grown in medium RPMI 1640 (Gibco Laboratories, Grand Island, NY), supplemented with $10 \%$ FCS, penicillin, streptomycin, and glutamine. MOLT4 cells were specifically chosen because previous studies demonstrated that these cells provide an excellent source of the 52- and 60-kD SSA/Ro components that are reliably recognized in immunoblotting by sera containing the respective antibodies (12). For use in immunoblotting, cells were washed twice with PBS, counted, pelleted, extracted in buffer containing $150 \mathrm{mM} \mathrm{NaCl}, 10 \mathrm{mM}$ Tris- $\mathrm{HCl}, \mathrm{pH}$ $7.2,0.5 \%$ NP-40, and freed of cell nuclei by centrifugation at $12,000 \mathrm{~g}$ for $15 \mathrm{~min}$. In preliminary experiments, various concentrations of cell and tissue lysates were electrophoresed on SDS gels and selected for the sharpest banding pattern after staining with Coomassie blue. For these conditions each lane used for immunoblot contained the total protein content of $2 \times 10^{6}$ solubilized cell equivalents, or $25 \mathrm{mg}$ of wet weight cardiac tissue.

Briefly, for RNA analysis, K562 cells at $0.5 \times 10^{6} / \mathrm{ml}$ were labeled with $25 \mu \mathrm{Ci} / \mathrm{ml}\left[{ }^{32} \mathrm{P}\right.$ ]orthophosphoric acid (carrier free, New England Nuclear, Boston, MA) in low phosphate DME (phosphate-free MEM [Gibco Laboratories]) at $37^{\circ} \mathrm{C}$ for $15 \mathrm{~h}$. Cells were harvested, washed in PBS, and lysed in buffer containing $10 \mathrm{mM}$ Tris pH 7.5, $10 \mathrm{mM} \mathrm{KCl}, 1$ $\mathrm{mM} \mathrm{Na}_{2}$ EDTA, $5 \mathrm{mM}$ iodoacetamide and $0.5 \mathrm{mM}$ PMSF at $10^{6} / 100$ $\mu \mathrm{l}$. After the cells were swollen on ice and sheared in a Dounce homogenizer, the lysate was rendered $200 \mathrm{mM}$ in $\mathrm{NaCl}$. Lysates were clarified by centrifugation and supernatants used immediately for immunoprecipitation of RNA.

RNA immunoprecipitation procedures. Protein A Sepharose (Pharmacia Fine Chemicals, Piscataway, NJ)-facilitated immunoprecipitation of labeled cellular antigen by antisera was performed as described (24). Briefly, $10 \mu$ l of each serum was added to $100 \mu l$ lysate $\left(10^{6}\right.$ cell equivalents) and the mixture incubated on ice for $10 \mathrm{~min} .40 \mu \mathrm{l}$ of $50 \%$ protein A-Sepharose was then added and incubated with rotation for $45 \mathrm{~min}$ at $4^{\circ} \mathrm{C}$. Beads were washed twice with mixed micelle buffer 150 $\mathrm{mM} \mathrm{NaCl}, 50 \mathrm{mM}$ Tris pH 7.5, $2 \mathrm{mM}$ EDTA, $0.25 \mathrm{M}$ sucrose, $2.5 \%$ Triton X-100 and $0.5 \%$ SDS, and three times in $150 \mathrm{mM} \mathrm{NaCl}, 50 \mathrm{mM}$ Tris pH 7.5, $2 \mathrm{mM} \mathrm{Na}_{2}$ EDTA. RNA was then extracted with phenol/ chloroform, precipitated with ethanol, and run on $7 \%$ polyacrylamide-7 $M$ urea gels. These were dried and the bands detected by autoradiography. 


\begin{tabular}{|c|c|c|c|c|c|c|c|c|c|c|c|}
\hline \multirow[b]{3}{*}{ Patient serum } & \multirow[b]{3}{*}{ Diagnosis } & \multirow[b]{3}{*}{ HLA type } & \multicolumn{6}{|c|}{ Antigen preparation (immunoblot) } & \multirow{2}{*}{\multicolumn{3}{|c|}{ RNA immunoprecipitation }} \\
\hline & & & \multicolumn{3}{|c|}{ MOLT 4 or $\mathrm{HeLa}^{*}$} & \multicolumn{3}{|c|}{ Fetal heart* } & & & \\
\hline & & & 60 & 52 & 48 & 60 & 52 & 48 & Y1-Y5 & 5SRNA & Pre tRNA \\
\hline & \multicolumn{11}{|c|}{$k D$} \\
\hline$A^{\ddagger}(7)$ & SLE & DR2, DR3 & - & - & + & - & - & + & + & + & + \\
\hline B & UAS & ND & - & - & + & - & - & + & + & + & + \\
\hline$C^{\ddagger}(33)$ & UAS & ND & - & - & + & & ND & & ND & ND & ND \\
\hline D & UAS & ND & - & - & + & - & - & + & + & + & + \\
\hline $\mathrm{E}(34)$ & SS & B8, DR3, DR7 & - & + & + & - & + & + & + & + & + \\
\hline$F$ & SLE & DR1, DR3 & - & + & + & - & + & + & + & + & + \\
\hline G & UAS & ND & - & + & + & & ND & & + & + & + \\
\hline H (33) & UAS & ND & - & + & + & & ND & & ND & ND & ND \\
\hline I (33) & UAS & ND & - & + & + & & ND & & ND & ND & ND \\
\hline $\mathbf{R}$ & UAS & ND & - & + & + & - & + & + & ND & ND & ND \\
\hline $\mathbf{T}$ & UAS & ND & - & + & + & - & + & + & ND & ND & ND \\
\hline $\mathbf{J}$ & SLE & B8, DR3, DR5 & + & + & + & - & + & + & + & + & + \\
\hline K (35) & UAS & B8, DR3 & + & + & + & + & + & + & + & + & + \\
\hline $\mathbf{L}^{\ddagger}$ & UAS & DR7 & + & + & + & + & + & + & + & + & + \\
\hline $\mathbf{M}$ & UAS & ND & + & + & + & + & + & + & + & + & + \\
\hline $\mathbf{N}$ & SS & DR4, DR3 & + & + & + & + & + & + & + & + & + \\
\hline$O(36)$ & UAS & ND & + & + & + & & ND & & ND & ND & ND \\
\hline $\mathbf{P}$ & SLE & DR3, DR6 & + & + & - & + & + & - & + & - & - \\
\hline $\mathbf{Q}$ & UAS & ND & + & + & - & + & + & - & + & - & - \\
\hline $\mathbf{S}$ & SLE & B8, DR3 & + & - & + & + & - & + & ND & ND & ND \\
\hline
\end{tabular}

* Antigen preparations from unfractionated cell lines or whole tissue. ${ }^{\ddagger}$ Cord blood from NLE neonate contained the same antibodies; $\mathrm{C}$ is from neonate with hepatic fibrosis. UAS, undifferentiated autoimmune state; mother has autoantibodies and some rheumatic symptoms, but does not fulfill ARA criteria for SLE, rheumatoid arthritis, or SS. ( ) next to the letters denotes a previously published reference on that individual.

Immunoblotting. Electrophoretic blotting was performed using the method of Towbin et al. (25) with some modifications. Briefly, proteins were separated by SDS-PAGE as described above and were electrotransferred to a nitrocellulose sheet for $3 \mathrm{~h}$ at constant voltage of 60 V. The nitrocellulose sheets were then incubated for $1 \mathrm{~h}$ in PBS containing $0.5 \%$ Tween 20 and $3 \%$ nonfat milk to block nonspecific binding sites. Then the nitrocellulose strips or sheets were incubated with a 1:100 dilution of sera and washed for $1 \mathrm{~h}$ in the Tween-PBS solution. In several instances the sera were also tested at a 1:10 dilution. ${ }^{125} \mathrm{I}$ Protein A (ICN Biochemicals, Irvine, CA) was used to detect bound human immunoglobulins.

HLA typing. HLA typing was performed by the standard National Institutes of Health microcytotoxicity assay (26).

Statistics. The odds ratios were calculated using the formula of Haldane. Probabilities were calculated by the Fisher exact probability method and the chi-square statistic, including the Yates correction.

\section{Results}

Detection of antibodies to SSA/Ro by immunoblotting. Using MOLT4 or HeLa cell lysates as an antigen preparation in immunoblotting, 16 of 20 pregnancy sera from mothers having infants with NLE contained antibodies reactive with peptides of the SSA/Ro particle. Only 9 of the 16 sera $(45 \%$ of the group) contained antibodies directed to the $60-\mathrm{kD}$ species while 15 (75\% of the group) contained antibodies reacting with the 52-kD component (Tables I and II). The reaction patterns of the sera of affected neonates were indistinguishable from those of their mothers (Table I). In comparison, among 31 pregnant patients with SLE or Sjögren's syndrome who had offspring without evidence of NLE only 12 sera contained antibodies to the SSA/Ro particle, $P<0.01$, demonstrable by immunoblotting (Table II). 10 of these 12 non-NLE mothers (32\% of the group) had antibodies to the $60-\mathrm{kD}$ SSA/Ro com-

Table II. Differences in the Frequency of Antibodies to Biochemically Defined 60-, 52-, and 48-kD Antigens of the SSA/Ro-SSB/La System in Mothers of Offspring with and without Neonatal Lupus

\begin{tabular}{|c|c|c|c|c|c|}
\hline \multirow[b]{2}{*}{$\begin{array}{c}M_{\mathrm{r}} \text { antigens } \\
\text { recognized }\end{array}$} & \multicolumn{2}{|c|}{ Antibody frequency } & \multirow[b]{2}{*}{$\begin{array}{l}\text { Odds ratio } \\
\text { (Haldane) }\end{array}$} & \multirow[b]{2}{*}{$\begin{array}{c}\chi^{2} \\
\text { (Yates) }\end{array}$} & \multirow[b]{2}{*}{$\begin{array}{c}\text { Probability } \\
\text { (Fisher) }\end{array}$} \\
\hline & $\begin{array}{c}\text { NLE present } \\
n=20\end{array}$ & $\begin{array}{c}\text { NLE absent } \\
n=31\end{array}$ & & & \\
\hline$k D$ & \multicolumn{2}{|c|}{$\%$} & & & \\
\hline 48 & 90 & 26 & 20.5 & 17.56 & $<0.001$ \\
\hline 52 & 75 & 32 & 5.8 & 7.26 & 0.003 \\
\hline 60 & 45 & 32 & 1.69 & 0.39 & $0.3 \mathrm{NS}^{*}$ \\
\hline 52 or $60^{\ddagger}$ & 80 & 39 & 6.1 & 7.43 & 0.003 \\
\hline
\end{tabular}

* NS, not significantly different from the null hypothesis of odds ratio of 1.0 .

₹ Total anti-SSA/Ro response: the frequency of individuals with antibodies to either the 52- or $60-\mathrm{kD}$ component of SSA/Ro. 
Table III. Different Frequencies of Antibody Response Patterns to 60-, 52-, and 48-kD Antigens of the SSA/Ro-SSB/La System in Mothers of Offspring with and without NLE

\begin{tabular}{lrrrr}
\hline $\begin{array}{c}M_{\mathrm{r}} \text { antigens } \\
\text { recognized }\end{array}$ & \multicolumn{2}{c}{$\begin{array}{c}\text { NLE present } \\
n=20\end{array}$} & \multicolumn{2}{c}{$\begin{array}{c}\text { NLE absent } \\
n=31\end{array}$} \\
\hline \multicolumn{1}{c}{$k D$} & No. & $\%$ & No. & $\%$ \\
48 & 4 & 20 & 2 & 6 \\
52,48 & 7 & 35 & 0 & 0 \\
$60,52,48$ & 6 & 30 & 5 & 16 \\
60,48 & 1 & 5 & 1 & 3 \\
60,52 & 2 & 10 & 3 & 10 \\
52 & 0 & 0 & 2 & 6 \\
60 & 0 & 0 & 1 & 3 \\
None & 0 & 0 & 17 & 55 \\
& & & & \\
\hline
\end{tabular}

ponent ( $P=$ NS vs. NLE mothers) and 10 of these sera (32\% of the group) had antibodies to the 52-kD Ro component ( $P$ $<0.01$ vs. NLE mothers). One SLE mother of an unaffected infant had antibodies only to the $60-\mathrm{kD}$ peptide, two had antibodies to the $52-\mathrm{kD}$ peptide alone; patterns not detected in any of the sera from the NLE mothers (Tables I and III).

Comparison of the immunoblots illustrated in Fig. 1 reacting with MOLT4 cell extracts to those illustrated in Fig. 2 using HeLa cell extracts revealed that the former preparation was a better source of the $60-\mathrm{kD}$ antigen, thereby providing a stronger signal for its detection. This is demonstrated by the comparison of Fig. 1, lane 9, and Fig. 2, lane 1, both studied with serum from the same affected mother, L. Of note, serum from affected mothers $\mathrm{E}$ and $\mathrm{F}$ reacted with the $52-\mathrm{kD}$ Ro component and not the $60-\mathrm{kD}$ on both substrates (Fig. 1, lanes 10 and 14, Fig. 2, lanes 6 and 10). In experiments not depicted, the possibility was explored that the weaker reactivity with the $60-\mathrm{kD}$ species reflected a lower titer of antibodies. Accordingly, the immunoblots were performed with antisera at a 10fold greater concentration. The pattern of reactivity remained unchanged emphasizing that antibodies to the $52-\mathrm{kD}$ component detectable by this method can occur independently from antibodies to the $60-\mathrm{kD}$ component.

Detection of antibodies to SSB/LA by immunoblot. Using MOLT4 or HeLa cell extracts, $90 \%$ of the NLE pregnancy sera had antibody profiles that included reactivity against the 48-kD SSB/La protein and its 43-kD degradation product (27). Only $26 \%$ of sera from mothers in the unaffected group had antibodies to SSB/La (Table II).

Table III lists the patterns of antibody responses to one or more components of the SSA/Ro-SSB/La complex detected upon immunoblotting in NLE and non-NLE pregnancies. The three most common patterns in the NLE group included antibodies recognizing the $48-\mathrm{kD} \mathrm{SSB} / \mathrm{La}$ antigen either in combination with antibodies directed to the 52-kD SSA/Ro component $(35 \%)$, in combination with antibodies against both the $52-$ and the $60-\mathrm{kD}$ Ro components $(30 \%)$ or in isolation $(20 \%)$ (Table III). The respective values in non-NLE mothers for the latter two profiles were 16 and $6 \%$. These differences were not statistically significant. However, of particular interest, there were no patients in the non-NLE group with antibodies simultaneously to both the $52-$ and $48-\mathrm{kD}$ components in the absence of reactivity to the $60-\mathrm{kD}$ component, although this was a prevalent antibody profile seen in the 20 individuals in the NLE group (odds ratio $=35, P<0.001$, Table III). In two individuals that had NLE in their offspring, serum was available for serial evaluation over a period of $3 \mathrm{yr}$. The antibody profiles which in one case included reactivity against the 52and $48-\mathrm{kD}$ peptides and the other against the $48-\mathrm{kD}$ peptide only, remained unchanged.

Detection of antibodies to SSA/Ro-SSB/La by Ouchterlony and ELISA. In the group of mothers with NLE offspring, eight of the eight sera tested that contained antibodies to the $60-\mathrm{kD}$ SSA/Ro species were reactive against the partially purified SSA/Ro bovine spleen preparation by ELISA. Of the 15 sera reacting with the $52-\mathrm{kD}$ component, 11 tested were reactive by ELISA. Of the four patients without detectable antibodies to SSA/Ro by immunoblotting all three tested contained weak reactivity against the SSA/Ro preparation by ELISA. One of

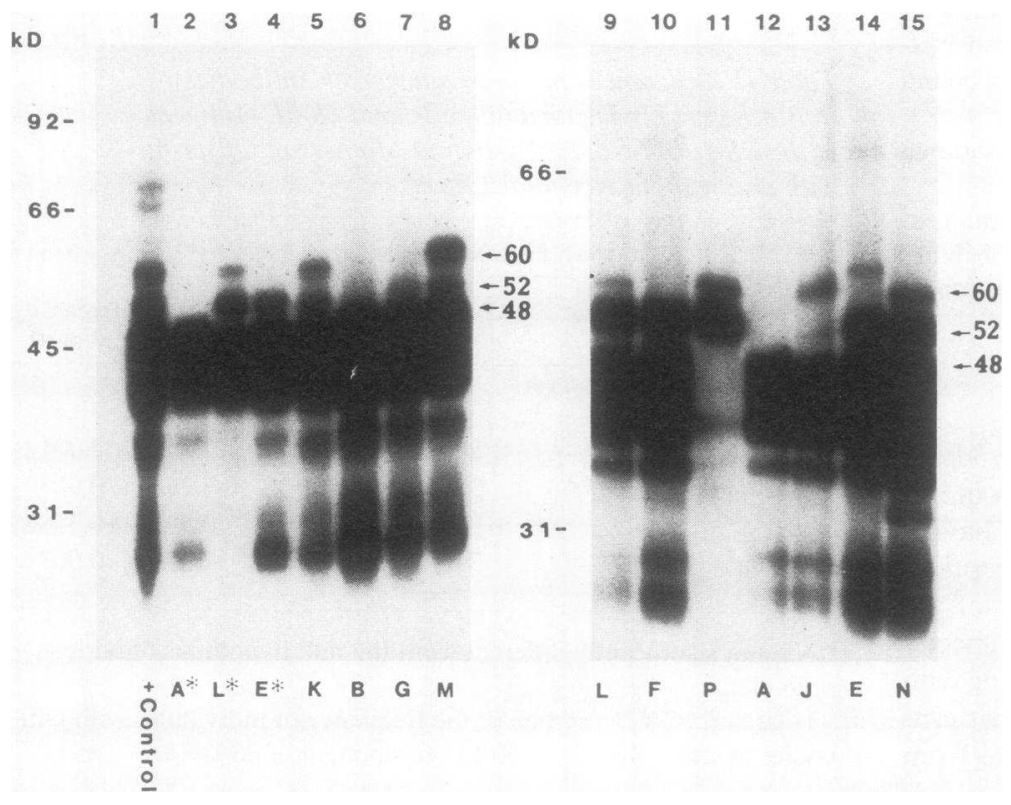

Figure 1. Immunoblotting analysis of reactivities of representative sera from mothers of offspring with NLE. An extract of MOLT4 cells, after gel electrophoresis and transfer to nitrocellulose, is incubated with a 1:100 dilution of the serum. The letters correspond to the assigned letter used in Table I. An asterisk (lanes 2-4) signifies serum from the paired cord blood. Bound human IgG was detected by ${ }^{125} \mathrm{I}$-protein $\mathrm{A}$. The serum in lane $I$ reacts with the 52-, 60-, and 48-kD peptides and is used as a prototype positive control (12). Arrows at the right of each gel identify the three major antigens: $60-\mathrm{kD}$, 52-kD, and 48-kD. Lanes $1-8$ and 9-15 represent separate gels as reflected by the difference in migration of the molecular weight markers. In many sera there are additional antibodies present distinct from those reactive with either the 60-, 52-, or 48-kD antigens. For example, serum from $E$ (lane 14) reacts with an antigen of molecular weight higher than the $60-\mathrm{kD}$ antigen. Many reactive polypeptides below native $48-\mathrm{kD} \mathrm{SSB} / \mathrm{La}$ are degradation products of the latter, including known 43,28 , and 23-kD polypeptides (27). 


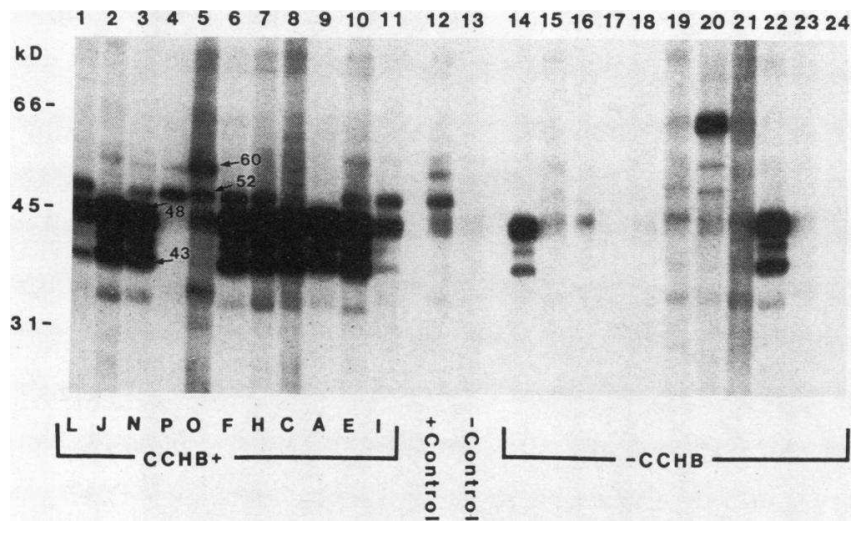

Figure 2. Representative immunoblot of reactivities of sera from mothers having offspring with and without NLE. The immunoblotting was performed exactly as described in Fig. 1 using an extract of HeLa cells. Again the letters under each lane denote serum obtained from one of the mothers with affected offspring and correspond to the assigned letter used in Table 1 . Lane 12 illustrates the same positive control serum used in Fig. 1. Lane 13 is probed with serum from a normal male individual. Lanes 14-24 are sera from a group of mothers with SLE who gave birth to healthy offspring (-CCHB). Arrows identify the locations of the 60-, 52-, 48-, and 43-kD bands.

these sera (patient $A$ ) was tested in double diffusion assays by our two laboratories with a variety of substrates and at different concentrations. In no instance could antibodies to SSA/Ro be demonstrated by reactions of identity with a reference serum. Because of the possibility that the SDS treatment of the antigen preparation might alter reactivity this serum was studied in immunoprecipitation using ${ }^{35}$ S-labeled MOLT4 cells. Under circumstances where all other tested sera gave typical SSA/Ro peptides of the appropriate apparent mass, serum A gave no evidence of reacting detectably with SSA/Ro peptides.

In the group of mothers with healthy offspring, 9 of 10 that contained antibodies reactive with the $60-\mathrm{kD}$ SSA/Ro were positive by ELISA with the bovine antigen. Similarly 9 of the 10 reactive with the 52-kD SSA/Ro peptide were positive by ELISA. One serum in this group reacted with both the 60 - and $52-\mathrm{kD}$ components but did not give a positive result on the
ELISA. Of the 14 sera from this group which were positive for SSA/Ro by ELISA, 4 were negative by immunoblot. In one serum, antibodies were detectable to SSA/Ro by ELISA but could not be detected by double diffusion experiments.

Immunoblot of extracts from fetal cardiac tissue. Because the central goal of this study was to characterize the antigenantibody systems associated with the development of NLE and specifically CCHB, the relative amounts of SSA/Ro and SSB/ $\mathrm{La}$ antigens were determined in fetal heart tissues, ages 18-24 wk. Using immunoblot analysis, the fetal heart antigen preparations contained a preponderance of SSB/La 48-kD antigen relative to either the 60 - or $52-\mathrm{kD} \mathrm{SSA} / \mathrm{Ro}$ antigen species (Figs. 3 and 4). The 52-kD SSA/Ro protein was seen to be present in all these fetal extracts, and gave a stronger signal relative to the $60-\mathrm{kD}$ antigen in the 18 -wk fetus. This pattern of 52-kD component predominance was also noted in a tissue extract of an 18-wk fetal liver and cord red blood cells as demonstrated by the reactivity of serum from mother $\mathbf{P}$ and the prototype positive control serum, which contains antibodies to both the 52- and the $60-\mathrm{kD}$ components defined using MOLT4 (Fig. 3).

Examination of the antibody specificities of 15 sera from NLE mothers using a cardiac extract of an 18-wk fetus reveals that all but one of the sera tested had anti-SSA/Ro profiles equivalent to those obtained with either MOLT4 or HeLa cell extracts (Table I, Fig. 4). The serum from individual J, which reacted with the $60-\mathrm{kD}$ Ro antigen in the HeLa and MOLT4 preparations did not react with the $60-\mathrm{kD}$ species in the fetal heart tissue (Fig. 4, lane 3). In contrast, this serum was weakly reactive against the 52-kD SSA/Ro component using MOLT4 cells, unreactive with the HeLa extract, but did demonstrate weak reactivity against the 52-kD Ro antigen in the heart preparation. Each of 13 mothers with anti-La antibodies defined on MOLT4 and HeLa cell extracts reacted with the $48-\mathrm{kD}$ antigen in the fetal heart.

Immunoprecipitation of ${ }^{32}$ P-labeled $R N A$. The RNA bands precipitated by sera from 13 CCHB mothers studied by this method confirmed the antibody profiles defined in the immunoblot analysis, Fig. 5, Table I. For example the two sera, $P$ and $\mathrm{Q}$, which contained antibodies to both the $52-$ and $60-\mathrm{kD}$ antigens and not the $48-\mathrm{kD}$ antigen precipitated the expected

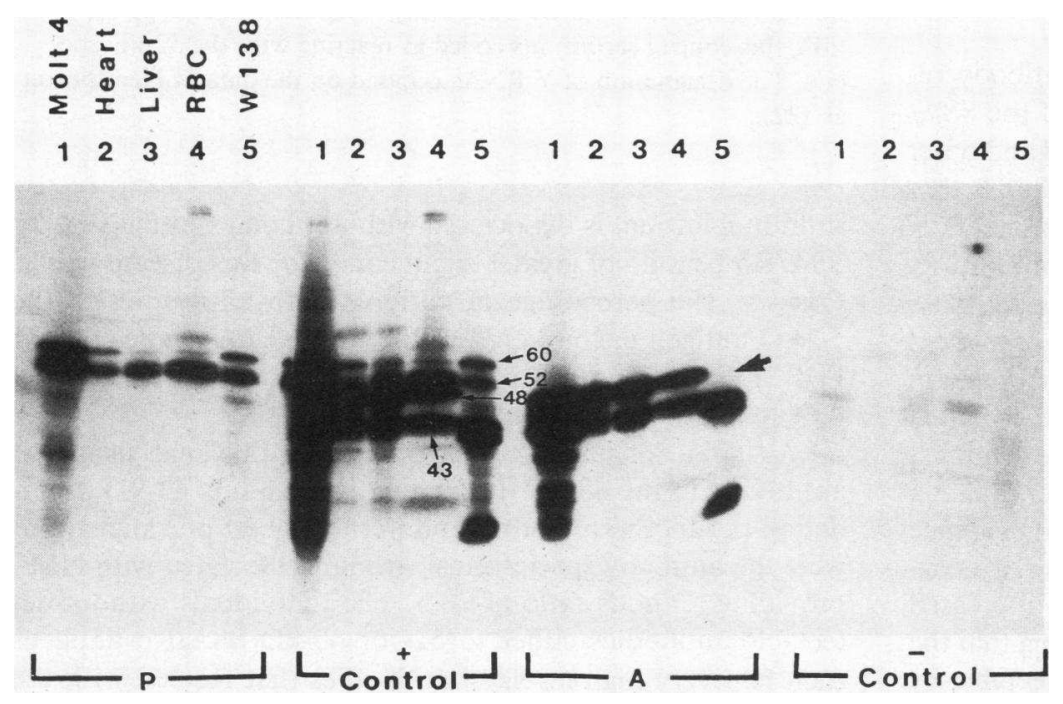

Figure 3. Immunoblotting analysis demonstrating the separate specificities of individuals $A$ and $P$ using extracts from several fetal tissues. The positive $(+)$ control is described in Fig. 1 . In this experiment the negative (-) control is a serum from a normal pregnant donor. In each set, lane 1 contains an extract of MOLT4, lane 2 is an extract of fetal cardiac tissue aged $18 \mathrm{wk}$, lane 3 is an extract of fetal liver aged 18 wk, lane 4 is an extract of cord red blood cells from a healthy neonate, and lane 5 is an extract of the cell line WI-38 derived from fetal lung fibroblasts aged 3 mo. Serum from individual $P$ has antibodies reactive with the 60-kD and 52-kD antigens. Serum from individual $A$ reacts with the $48-\mathrm{kD}$ and $43-\mathrm{kD}$ antigens of the SSB/LA system. Note in lane 5 probed with serum from individual $A$ there is no apparent $48-\mathrm{kD}$ band (large arrow), suggesting that the SSB/LA has been degraded. This is corroborated in lane 5 probed with the positive control where only the $60-, 52-$, and 43-kD bands are present. The smaller arrows identify the locations of the 60-, 52-, 48-, and 43-kD bands. 


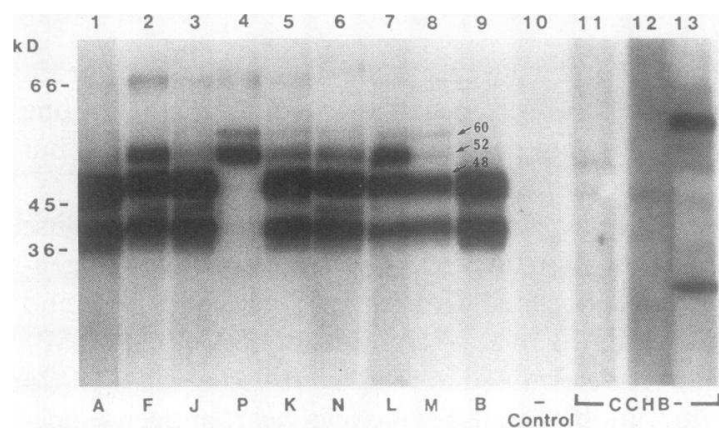

Figure 4. Representative immunoblot using fetal cardiac tissue aged $18 \mathrm{wk}$ and probed with sera from mothers of affected and unaffected offspring. The letters under the lane correspond to the sera of mothers with NLE offspring exactly as assigned in Table I. Lane 10 is probed with serum from a normal donor. Lanes 11-13 are probed with sera from three pregnant lupus patients carrying healthy fetuses $(-\mathrm{CCHB})$.

RNA species hY1-hY5 associated with the SSA/Ro particle and curiously in one case immunoprecipitated an RNA species of mass similar to tRNA. The remaining 11 sera precipitated the SSB/La associated RNA species, including the 5S RNA and tRNA precursors, as well as the hY1-hY5 species, emphasizing the predominance of the anti SSB/La antigen response in these sera. Of particular interest, the only set of RNA species uniformly precipitated by all of the mothers of NLE children was the hY1-hY5 system.

HLA typing. In agreement with previously published immunogenetic studies (28), there was a high frequency of the DR3 phenotype in mothers of offspring with NLE (Table I). Eight of nine affected mothers evaluated in this study were DR3. However, DR3 was found with all patterns of antibody response, including the presence of detectable antibodies to SSB/La. Six of these eight DR3-positive women had antibodies to the 52-kD SSA/Ro antigen. The one DR3-negative individual, $\mathrm{L}$, had antibodies to the 52-kD antigen. In mothers of unaffected offspring, 12 of 25 were DR3. Of these 12, 5 had antibodies to the $52-\mathrm{kD}$ antigen. In this group, there were three mothers who had antibodies to the $52-\mathrm{kD}$ protein but were not DR3.

\section{Discussion}

In this study, we initiated the definition of the antibody response to molecularly characterized components of the SSA/ Ro-SSB/La system in mothers of infants with $\mathrm{CCHB}$ and other permanent manifestations of NLE. The central finding is that all individuals have antibodies to one or more components of the SSA/Ro-SSB/La system, identified by immunoblotting, but that no antibody to a single antigen detectable by these methods is uniformly demonstrable. As has been emphasized by other workers (2-4), antibodies to the SSA/Ro particle are commonly encountered. Here, surprisingly, antibodies to the well-characterized $60-\mathrm{kD}$ SSA/Ro polypeptide, although present, were not significantly increased in frequency over that in a control group of mothers who had SLE or SS without evidence of fetal heart block. In contrast, antibodies to the newly recognized 52-kD SSA/Ro polypeptide were significantly increased in the NLE group ( 75 vs. $32 \%, P<0.01$ ), emphasizing that the immune response to these two components, as detectable by

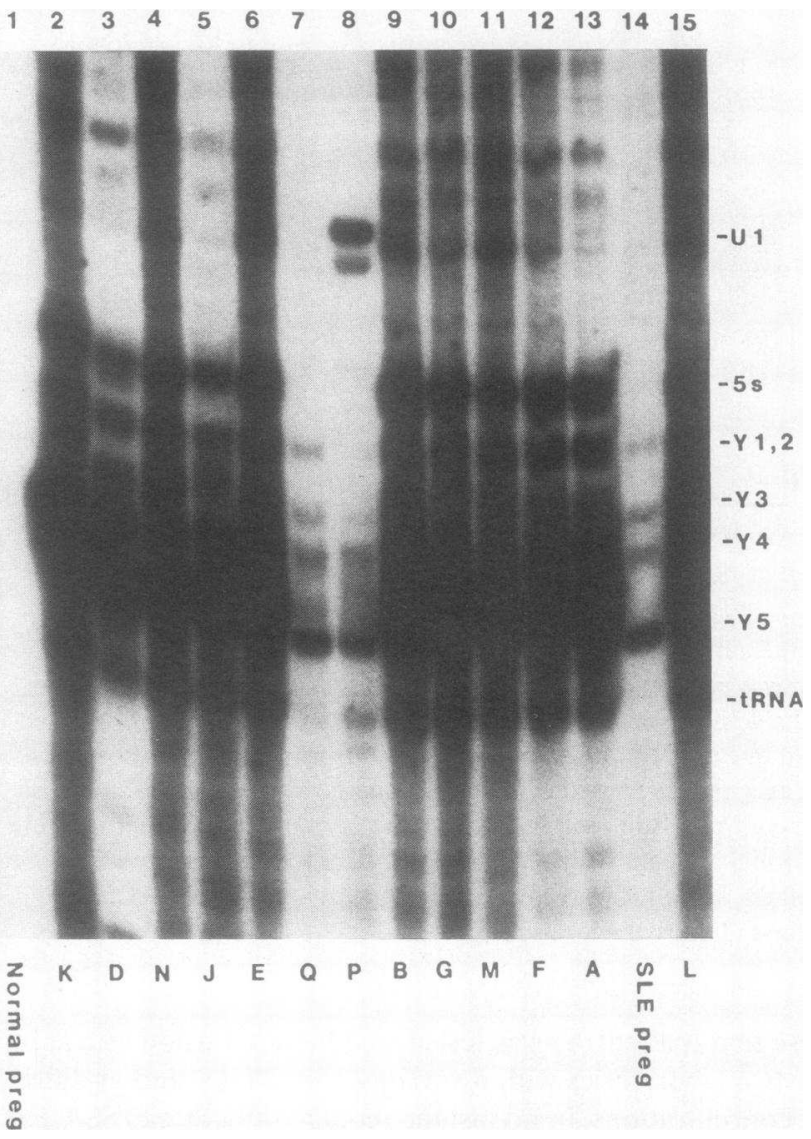

Figure 5. Immunoprecipitation of $\left.{ }^{32} \mathrm{P}\right]$ orthophosphate-labeled $\mathrm{K} 562$ cell extract by sera from 13 mothers of offspring with CCHB. RNA was extracted from the immunoprecipitate by phenol, precipitated with ethanol, and analyzed on a 7-M urea, $7 \%$ polyacrylamide gel. Lane 1 is a precipitate from the serum of a healthy pregnant donor. The letters under the lanes again correspond to the serum of affected mothers exactly as assigned in Table $I$ and the preceding figures. Lanes 2-6 (K, D, N, J, E) and lanes 9-15 (B, G, M, F, A, L) demonstrate the RNA's precipitated by sera containing anti-48-kD antibodies either alone or in combination with anti-52- or $60-\mathrm{kD}$ antibodies. Lanes 7 and $8(\mathrm{Q}$ and $\mathrm{P})$ demonstrate the RNAs precipitated by sera containing both anti-60-kD and anti-52-kD antibodies. Lane 14 demonstrates the RNA's precipitated by a pregnant lupus patient who subsequently gave birth to a healthy offspring. Note that although this serum brings down the spectrum of RNAs associated with the SSA/Ro particle, by immunoblotting, it detects a species migrating slightly $>52 \mathrm{kD}$ but clearly $<60 \mathrm{kD}$. For data presentation, this control serum was coded as reacting with the 52-kD species. The designation of Y RNAs is based on the data of Hendrick et al. (32).

immunoblotting, is dissociable with antibodies to the smaller SSA/Ro peptide of greater significance for this disease entity. Of note, the percentage of patients with antibodies to the $52-\mathrm{kD}$ antigen encountered in the non-NLE group (29 of 31 had SLE) was similar to the recently reported frequency of $43 \%$ in a group of SLE patients (29).

A significant point that emerged from this analysis is that antibodies to the 48-kD SSB/La antigen and its 43-kD degradation product were both found in the highest prevalence and were the antibody species most strongly associated with NLE, providing an odds ratio of 20.5. The individuals without detectable antibodies either to $52-$ or $60-\mathrm{kD}$ SSA/Ro antigens each had very high levels of antibodies that reacted with the 
SSB/La polypeptides. Moreover, the combination of antibodies demonstrable to both the 48-kD SSB/La polypeptide and the 52-kD SSA/Ro polypeptide, but not to the 60-kD SSA/Ro species, was most strongly associated with the occurrence of NLE, odds ratio 35 . The results of the ${ }^{32}$ P-RNA immunoprecipitated by the antibodies paralleled the specificities of the peptides identified by immunoblotting with the interesting exception of a band with apparent mass of tRNA in serum $P$ that does not react detectably with the 48-kD La peptide. Of interest, the hY1-5 species were found in the precipitates of all NLE sera studied, suggesting that perhaps a polypeptide associated with these RNA species could have a special relationship to the pathogenesis of NLE.

Support for the possible importance of the particle containing the $48-\mathrm{kD}$ SSB/La peptide as directly relevant to the pathogenesis of NLE came from analysis of fetal cardiac tissue that had abundant 48-kD SSB/La peptide demonstrable. In addition, the 52-kD SSA/Ro species was readily evident, although at lower levels, while still smaller quantities of the $60-\mathrm{kD}$ peptide were found. A similar pattern of peptide abundance was seen in several other cell lines. Nevertheless, the detectability of certain peptides varied according to the source of the cells. Particular attention had to be directed to developing analytic electrophoretic conditions that reliably separated the $48-\mathrm{kD}$ La protein and the $52-\mathrm{kD}$ Ro protein. The antigen unrelatedness of these species is demonstrated in Fig. 3 using a preparation in which one serum reacts with the intact $52-\mathrm{kD}$ component while another serum reacts only with the lower molecular weight SSB/La degradation components. In the course of this work we found that the detection method that used ${ }^{125}$ I-Protein A was distinctly superior to those methods using an alkaline phosphatase-based system involving antihuman Ig antibodies. In particular, fetal cardiac extracts yielded a band, tentatively identified as actin, which partially overlapped and often interfered with the detection of the $52-\mathrm{kD}$ protein when rabbit or goat anti-human IgG antibodies were used (data not shown). This interference was not encountered with radiolabeled Protein A. Particular attention to the washing steps was also necessary to achieve a low overall background.

Although this study did not address the interrelationship of the 52- and 60-kD SSA/Ro polypeptides, it provides further support for their operational independence by demonstrating maternal sera with separate specificities for the 52-kD component. Additionally, earlier studies demonstrated the lack of cross-reactivity between antibodies affinity purified from each protein as well as the lack of common protease-resistant fragments in the partial proteolysis of the proteins (12). Although evidence mounts concerning how the 52-kD SSA/Ro antigen differs from the $60-\mathrm{kD}$ antigen, in their native state both of these polypeptides appear to exist as a complex with hY1-hY5 molecules. Furthermore, although none of the affected mothers had antibodies exclusively reactive against the 52-kD antigen, previous work has shown that the small RNA species precipitated by anti-52-kD antibodies are identical to that precipitated by antibodies to the $60-\mathrm{kD}$ alone (12). In the two NLE mothers with reactivity against both SSA/Ro components, the precipitated RNA species were the expected hY1. hY5 associated with SSA/Ro. Of interest it is possible that the 52-kD SSA/Ro species was recognized but not identified in a report stating monospecific anti-Ro sera recognized a $50-\mathrm{kD}$ protein on immunoblotting, considered to be SSB/La but which did not precipitate the expected SSB/La associated
RNAs (9). In retrospect, these sera may have identified the 52-kD SSA/Ro peptide component.

Although the central point of this study was to analyze the specificity of the autoantibodies in mothers of infants with NLE using resolving methods that permit identification of the autoantigens, at least in terms of apparent mass, the results have some relevance to the general area of testing antibodies to SSA/Ro-SSB/La by ELISA and double diffusion methods. Pending the cloning and expression of all the peptides of the SSA/Ro-SSB/La particle that will provide a definitive answer to issues of sensitivity and specificity of antibody detectability and antigen definition, each currently available method has advantages and disadvantages. In principle, for example, as a screening test, the specificity of immunoblotting can be offset by a lack of sensitivity, especially for epitopes altered by denaturation and a bias to high affinity antibodies. In contrast, the sensitivity of ELISA methods may be circumscribed by the presence of minute quantities of contaminating antigen. It was of interest to encounter several sera that reacted with purified bovine SSA/Ro by ELISA but that did not yield demonstrable $52-$ or $60-\mathrm{kD}$ bands with the immunoblotting procedure. One interpretation of the former observation is that certain epitopes on SSA/Ro peptides might be altered by denaturation. In support of this is the finding by Ben-Chetrit et al. that 6 of 42 sera containing antibodies to SSA/Ro demonstrable in double diffusion analysis were not reactive in immunoblotting (12). In contrast, the specificities of the NLE sera appear distinctive in that they are predominantly directed to epitopes on SSA/RoSSB/La peptides that resist the denaturing effect of SDS, electrophoresis, and transfer. Reciprocally, some evidence suggests that sera containing abundantly detectable antibodies to the 52-kD SSA/Ro peptide using a human antigen preparation did not react with the partially purified bovine SSA/Ro antigen preparation. With respect to the latter observation, the variations in reactivity in ELISA systems that result from speciesrelated differences in structure of the SSA/Ro particle have been the subject of detailed study (30).

The biologic relevance of antibodies demonstrable with immunoblot techniques to the intracellular 48-, 52-, and $60-\mathrm{kD}$ antigens in the pathogenesis of NLE remains unknown. Although the presence of antibodies reactive in this technique appears to be a characteristic of these patients, the antibodies are not in themselves sufficient for the development of the syndrome. Indeed, these antibodies could be only clinically useful markers of the production of antibodies to an unrelated but conformationally equivalent membrane structure. Alternatively, as previously suggested (31), translocation of a component of intracellular SSA/Ro to the cell surface may be a critical element. However, that the common feature of each NLE mother is the production of antibodies to some, and often different, elements of the SSA/Ro-SSB/La particle assembly directs attention both to the regulation of the production of these autoantibodies and to the cell biology of this particle assembly and its possible unique function during the stage of cardiac development when the fetus, but not the mother, is at risk for this syndrome.

\section{Acknowledgments}

We appreciate the generosity of Drs. Rene Norberg, Patricia Hopkins, and Laxmi Baxi in providing certain sera from mothers of offspring with CCHB. We thank Dr. Harry Shen for assistance in the HLA typing, Carole Peebles for technical assistance, and Lillian Richman for preparation of the manuscript.

This work was supported in part by National Institutes of Health 
grants AI-19411-09, AR-32063, and RR-05589-19, and an Arthritis Foundation Clinical Research Center grant.

\section{References}

1. Buyon, J., and I. Szer. 1986. Passively acquired autoimmunity and the maternal fetal dyad in systemic lupus erythematosus. Semin. Immunopathol. 9:283-304.

2. Lee, L. A., B. R. Reed, C. Harmon, R. Wolfe, J. Wiggins, C. Peebles, W. L. Weston, and R. Harmon. 1983. Autoantibodies to SSA/Ro in congenital heart block. Arthritis Rheum. 20:S24. (Abstr.)

3. Scott, J. S., P. J. Maddison, P. V. Taylor, E. Esscher, O. Scott, and R. P. Skinner. 1983. Connective tissue disease, autoantibodies to ribonucleoprotein and congenital heart block. N. Engl. J. Med. 309:209-212.

4. Watson, R. M., A. T. Lane, N. K. Barnett, W. B. Bias, F. C. Arnett, and T. T. Provost. 1984. Neonatal lupus erythematosus: a clinical, serological and immunogenetic study with review of the literature. Medicine (Baltimore). 63:362-378.

5. Deng, J. S., L. W. Bair, Jr., S. Shen-Schwartz, R. Ramsey-Goldman, and T. Medsger, Jr. 1987. Localization of Ro(SS-A) antigen in the cardiac conduction system. Arthritis Rheum. 30:1232-1238.

6. Deng, J. S., R. D. Sontheimer, and J. N. Gilliam. 1985. Expression of Ro/SS-A antigen in human skin and heart. J. Invest. Dermatol. 85:412-416.

7. Buyon, J. P., S. Swersky, H. Fox, F. Bierman, and R. J. Winchester. 1987. Intrauterine therapy for presumptive fetal myocarditis with acquired heart block due to systemic lupus erythematosus: experience in a mother with a predominance of SSB/LA antibodies. Arthritis Rheum. 30:44-49.

8. Schrieber, L., M. McCredie, C. Jelermajer, G. Scholler, D. Kelly, T. Chivers, and Y. Wang. 1988. A case control study of congenital heart block (CHB): association with maternal antibodies to $\mathrm{La}(\mathrm{SS}-\mathrm{B})$. Arthritis Rheum. 31:S66. (Abstr.)

9. Wolin, S. L., and J. A. Steitz. 1984. The Ro small cytoplasmic ribonucleoprotein: identification of the antigenic protein and its binding site on the Ro RNA's. Proc. Natl. Acad. Sci. USA. 81:1996-2000.

10. Ben-Chetrit, E., B. J. Gandy, E. M. Tan, and K. F. Sullivan. Isolation and characterization of a cDNA clone encoding the $60-\mathrm{kD}$ component of the human SS-A/Ro ribonucleoprotein autoantigen. $J$. Clin. Invest. 83:1284-1292.

11. Lieu, T. S., M. M. Newkirk, J. D. Capra, and R. D. Sontheimer. 1988. Molecular characterization of human Ro/SS-A antigen. Amino terminal sequence of the protein moiety of human Ro/SS-A antigen and immunological activity of a corresponding synthetic peptide. $J$. Clin. Invest. 82:96-101.

12. Ben-Chetrit, E., E. K. L. Chan, K. F. Sullivan, and E. M. Tan. 1988. A 52-kD protein is a novel component of the SS-A/Ro antigenic particle. J. Exp. Med. 162:1560-1571.

13. Rader, M. D., C. O'Brien, Y. Lieu, J. B. Harley, and M. Reichlin. 1987. Heterogeneity of the Ro SS-A Antigen: different molecular forms in lymphocytes and red blood cells. J. Clin. Invest. 83:12931298.

14. Lerner, M. R., J. A. Boyle, J. A. Hardin, and J. A. Steitz. 1981. Two novel classes of small ribonucleoproteins detected by antibodies associated with lupus erythematosus. Science (Wash. DC). 211:400402.

15. Deng, J. S., R. D. Sontheimer, and J. N. Gilliam. 1985. Molecular characteristics of SS-B/La and SS-A/Ro cellular antigens. J. Invest. Dermatol. 84:86-90.

16. Chambers, J. C., and J. D. Keene. 1985. Isolation and analysis of cDNA clones expressing human lupus La antigen. Proc. Natl. Acad. Sci. USA. 82:2115-2119.

17. Sturgess, A. D., M. G. Peterson, L. J. McNeilage, S. Whittingham, and R. L. Cappel. 1988. Characteristics and epitope mapping of a cloned human autoantigen La. J. Immunol. 140:3212-3218.

18. Rinke, J., and J. A. Steitz. 1982. Precursor molecules of both human 5S ribosomal RNA and transfer RNAs are bound by a cellular protein reactive with anti-La lupus antibodies. Cell. 29:149-159.

19. Gottlieb, E., and J. A. Steitz. 1987. The mammalian La protein associates with known transcription components in RNA polymerase and the regulation of transcription. Proceedings of the Sixteenth Steenbock Symposium. University of Wisconsin at Madison. 13-17 July, 1986. W. S. Reznikoff, R. R. Burgess, J. E. Dahlberg, L. A. Gross, M. T. Record, Jr., and M. P. Wickens, editors. Elsevier/North Holland, Amsterdam. 465-468.

20. Fox, R. I., C. A. Robinson, J. G. Curd, F. Kozin, and F. V. Howell. 1986. Sjögren's syndrome: proposed criteria for classification. Arthritis Rheum. 29:577-584.

21. Tan, E. M., A. S. Cohen, J. F. Fries, A. T. Masi, D. J. McShane, N. F. Rothfield, J. G. Schalter, N. Talal, and R. J. Winchester. 1982. The 1982 revised criteria for the classification of systemic lupus erythematosus. Arthritis Rheum. 25:1271-1277.

22. Lockshin, M. D., E. Bonfa, K. Elkon, and M. L. Druzin. 1988. Neonatal lupus risk to newborns of mothers with systemic lupus erythematosus. Arthritis Rheum. 31:697-701.

23. Laemmli, U. K. 1970. Cleavage of structural protein during the assembly of the head of bacteriophage T4. Nature (Lond.). 227:680685.

24. Reeves, W. H., D. E. Fisher, R. Wisniewolski, A. B. Gottlieb, and N. Chiorazzi. 1986. Psoriasis and Raynaud's phenomenon associated with autoantibodies to $\mathrm{U} 1$ and $\mathrm{U} 2$ small nuclear ribonucleoproteins. N. Engl. J. Med. 315:105-111.

25. Towbin, H. T., J. Staehelin, and J. Gordon. 1979. Electrophoretic transfer of proteins from polyacrylamide gels to nitrocellulose sheets. Procedures and applications. Proc. Natl. Acad. Sci. USA. 76:4350-4354.

26. Nunez-Roldan, A., I. Szer, T. Toguchi, J. Cuttner, and R. Winchester. 1982. Association of certain Ia allotypes with the occurrence of chronic lymphocytic leukemia, recognition by a monoclonal anti-Ia reagent of a susceptibility determinant not in the DR series. $J$. Exp. Med. 156:1872.

27. Chan, E. K. L., A. M. Francour, and E. M. Tan. 1986. Epitopes, structural domains and asymmetry of amino acid residues in SS-B/La nuclear protein. J. Immunol. 136:3744-3749.

28. Lee, L. A., W. B. Bias, F. C. Arnett, C. Huff, D. A. Norris, C. Harmon, T. T. Provost, and W. L. Weston. 1983. Immunogenetics of the neonatal lupus syndrome. Ann. Intern. Med. 99:592-596.

29. Ben-Chetrit, E., E. K. L. Chan, K. F. Sullivan, R. I. Fox, and E. M. Tan. 1988. SS-A/Ro antigen(s) are $52 \mathrm{kD}$ and $60 \mathrm{kD}$ proteins and their autoantibodies reveal differences between primary Sjögren's Syndrome (SS) and SLE. Arthritis Rheum. 31:S64. (Abstr.).

30. Rosario, M. O., O. F. Fox, E. Koren, and J. B. Harley. 1988. Anti-Ro (SS-A) antibodies from Ro(SS-A)-immunized mice. Arthritis Rheum. 31:227-236.

31. LeFeber, W. P., D. A. Norris, S. R. Ryan, L. A. Lee, J. C. Huff, M. Kubo, S. T. Boyce, B. L. Kotzin, and W. L. Weston. 1984. Ultraviolet light induces binding of antibodies to selected nuclear antigens on cultured human keratinocytes. J. Clin. Invest. 74:1545-1551.

32. Hendrick, J. P., S. L. Wolin, J. Rinke, M. R. Lerner, and J. A. Steitz. 1981. Ro small cytoplasmic ribonucleoproteins are a subclass of La ribonucleoproteins: further characterization of the Ro and La small ribonucleoproteins from uninfected mammalian cells. Mol. Cell. Biol. 1:1138-1149.

33. Franco, H. L., W. L. Weston, C. Peebles, S. L. Forstot, and P. Phanuphak. 1981. Autoantibodies directed against sicca syndrome antigens in the neonatal lupus syndrome. J. Am. Acad. Dermatol. 4:67-72.

34. Buyon, J., R. Roubey, S. Swersky, L. Pompeo, A. Parke, L. Baxi, and R. Winchester. 1988. Complete congenital heart block: risk of occurrence and therapeutic approach to prevention. J. Rheumatol. 15:1104-1108.

35. Bierman, F., L. Baxi, I. Jaffe, and J. Driscoll. 1988. Fetal hydrops and complete congenital heart block: response to maternal steroid therapy. J. Pediatr. 112:646-648.

36. Litsey, S. E., J. A. Noonan, W. N. O'Connor, C. M. Cotrill, and B. Mitchell. 1985. Maternal connective tissue disease and congenital heart block: demonstration of immunoglobulin in cardiac tissue. $N$. Engl. J. Med. 312:98-100. 